\title{
Preparation of soy protein hydrolysates with antioxidant activity by using peptidases from latex of Maclura pomifera fruits
}

\author{
Andrea Milagros Reyes Jara ${ }^{\mathrm{a}}$, Constanza Silvina Liggieri ${ }^{\mathrm{b}}$, Mariela Anahí Bruno ${ }^{\mathrm{b}, *}$ \\ a Instituto de Fisiología Vegetal (INFIVE), Universidad Nacional de La Plata (UNLP), CONICET, 113 and 61, 1900 La Plata, Argentina \\ b CIPROVE-Centro Asociado CICPBA, Departamento de Ciencias Biológicas, Facultad de Ciencias Exactas, UNLP, Calle 47 y 115 S/N, B1900AJL La Plata, Argentina
}

\section{A R T I C L E I N F O}

\section{Keywords:}

Maclura pomifera

Plant peptidases

Soybean-protein isolate

Protein hydrolysate

Bioactive peptide

Antioxidant activity

\begin{abstract}
A B S T R A C T
A partially purified proteolytic extract prepared from Maclura pomifera latex was employed in hydrolyzing a soybean-protein isolate $(4.2 \mathrm{mg} / \mathrm{mL})$. The hydrolysis-product formation, monitored by tricine-sodium-dodecylsulfate-polyacrylamyde-gel electrophoresis and reverse-phase high-performance liquid chromatography, indicated that after $10 \mathrm{~min}$ of reaction the main soybean proteins disappeared. The maximum degree of hydrolysis was $36.2 \%$ after a 180 -min digestion. The 90 -min hydrolysate presented an $\mathrm{IC}_{50}$ of $31.6 \pm 0.2 \mu \mathrm{g} / \mathrm{mL}$, and a trolox equivalent antioxidant capacity of 157.6 and $176.9 \mu$ moles TE per $g$ of peptide determined by two different methods. Analysis by matrix-assisted-laser-desorption-ionization-time-of-flight mass spectrometry (MALDI-TOF MS), followed by the application of bioinformatics tools, enabled the deduction of fourteen theoretical peptide sequences containing antioxidant amino acids at $>60 \%$, none of which sequences had been previously reported as antioxidants. Finally, we consider that this 90 -min hydrolysate would constitute a promising ingredient in the manufacture of functional foods.
\end{abstract}

\section{Introduction}

Reactive-oxygen species (ROSs) are a group of compounds that includes oxygen radicals and several nonradical oxidizing agents, which have tendency to donate oxygen to other substances (Kumar, 2011). Free radicals are species with unpaired electrons that are unstable and rapidly carry out a series of chain reactions with other compounds. ROSs provoke harmful effects on the cell through damage of DNA, oxidations of lipids, oxidations of amino-acid residues in proteins, and inactivation of the cofactors of enzymes (Sarma, Mallick, \& Ghosh, 2010). ROSs can be generated in the body either as a result of metabolic reactions or in pathologic states, as well as into the food. In living organisms, ROSs can be combatted by specific enzyme systems and through both endogenous antioxidants such as glutathione and exogenous antioxidant compounds such as vitamin C (Griffiths et al., 2016; Kumar, 2011; Peng et al., 2014). Oxidation reactions furthermore affect the quality of foods by modifying the organoleptic characteristics (De Castro \& Sato, 2015). Antioxidants are therefore used to preserve foods by retarding the deterioration, rancidity, or discoloration caused by such oxidation and thus contribute to the field of healthcare through protecting the body against damage by ROSs (Kumar, 2011). The search for effective, nontoxic natural antioxidants has been intensified in recent years since certain frequently used synthetic antioxidants (e.g., butylated hydroxytoluene and butylated hydroxyanisole) have recently been reported to be hazardous to human health (Akbarirad, Gohari Ardabili, Kazemeini, \& Mousavi Khaneghah, 2016; Lobo, Patil, Phatak, \& Chandra, 2010).

Plant-derived foods-i. e., fruits, vegetables, cereal grains, and seeds-contain natural antioxidants that can confer on the body a significant protection against ROS-induced oxidative stress (Waly et al., 2016). Mediterranean-style diets have been known cause a significant decline in cardiovascular diseases through an intervention in lipoprotein oxidation with a consequent reduction in oxidative stress. Vegetables, fruits, tea, and wine contain flavonoid antioxidants that can reduce coronary disease and even cancer (Griffiths et al., 2016).

Other food-compounds that offer action against oxidation are peptides from either animal or plant sources. Bioactive peptides-fragments encrypted in the primary sequences of proteins that confer different biologic activities including antioxidation-are released through the hydrolysis of peptide bonds by peptidases (Li-Chan, 2015). Antioxidant peptides have been identified in protein hydrolysates of milk, egg, meat, and fish (Abu-Salem, Mahmoud, El-Kalyoub, Gibriel, \& Abou-Arab, 2013; Ahmed, El-Bassiony, Elmalt, \& Ibrahim, 2015; Erdmann, Cheung, \& Schröder, 2008). The plant sources of protein hydrolysates with antioxidant activity are wheat, rice, oats, corn, soybean, peas, and chickpeas. The soybean is one of the most widely

\footnotetext{
* Corresponding author.

E-mail addresses: areyesjara@quimica.unlp.edu.ar (A.M. Reyes Jara), cliggieri@biol.unlp.edu.ar (C.S. Liggieri), brunomariela@biol.unlp.edu.ar (M.A. Bruno).
} 
studied sources of antioxidant peptides (De Castro \& Sato, 2015). Puchalska, Marina, and García (2014) reported the presence of at least thirty such peptides in a fraction smaller than $3 \mathrm{kDa}$ of five soybeanbased infant commercial formulas. The peptide SGDAL had been previously reported but within the two longer sequences of antioxidant peptides LQSGDALRVPSGTTYY and LNSGDALRVPSGTTYY from soybean $ß$-conglycinin.

The peptidases employed in digestion reactions can be commercial enzymes, such as Alcalase $\mathrm{e}^{\mathrm{TM}}$ and trypsin, or ones from nontraditional sources, such as those from plants. The digestion conditions and enzyme-specificities are key parameters in protein hydrolysis for determining the peptide-bonds to be cleaved. The resulting hydrolysates exhibit bioactive properties that are related to changes in protein structure, a reduction in molecular mass, and the surface-exposure of both ionizable and hydrophobic groups (Evangelho et al., 2016). With respect to the mechanism of action of antioxidant peptides, several studies demonstrated an ability to inhibit lipid peroxidation, to remove free radicals, to chelate metal ions, and to eliminate ROSs. The composition of antioxidant peptides is a key consideration: Tyr, Trp, Met, Lys, and Cys have been reported to be able to reduce $\mathrm{Fe}^{+3}$ to $\mathrm{Fe}^{+2}$, and chelate $\mathrm{Fe}^{+2}$ and $\mathrm{Cu}^{+2}$ ions. In addition, Trp, Tyr, and Phe-the aromatic amino acids-may scavenge certain radicals by proton donation from the pi orbital of the benzene ring. The basic amino acid His presents a great potential in radical scavenging by chelating, lipid trapping, and decomposition of the imidazole ring. In addition, the sequence of a given peptide also plays a key role in determining the resulting antioxidant activity (De Castro \& Sato, 2015). Abu-Salem et al. (2013) compared the antioxidant capability of 28 structurally related peptides to Leu-Leu-Pro-His-His from soybean-protein digests and concluded that Pro-His-His could be an active center to confer antioxidant activity on the entire peptide. Maclura pomifera (Raf.) Schneid (Moraceae) is an ornamental species cultivated in Argentina, whose fruit latex contains unusual quantities of serine peptidases that have been used to hydrolyze bovine-whey proteins (Bertucci, Liggieri, Colombo, Vairo Cavalli, \& Bruno, 2015) and bovine caseins (Corrons, Liggieri, Trejo, \& Bruno, 2017). These hydrolysates were prepared under mild reaction conditions, and both contain angiotensin-converting-enzyme-inhibitory biopeptides. On the basis of the observations described above, we propose as hypothesis of work that peptidases from M. pomifera could be capable of hydrolyzing soybean proteins to release the antioxidant peptides present in those food sources. The present study was thus aimed at employing those peptidases to produce hydrolysates of soybean proteins after optimizing the digestion conditions and then monitoring the hydrolysis products to determine the presence of antioxidant activity. The general objective was to prepare a product that can be used as an ingredient in functional foods.

\section{Materials and methods}

\subsection{Chemicals}

Bovine-serum albumin, 2,2'-azino-bis(3-ethylbenzothiazoline-6-sulfonic acid (ABTS), casein, 2,4,6-trinitrobenzenesulfonic acid (TNBS), Lcysteine, potassium persulfate, tris(hydroxymethyl)aminomethane (Tris), 2,2'-Azobis(2-methylpropionamidine) dihydrochloride (AAPH), and 6-hydroxy-2,5,7,8-tetramethylchromane-2-carboxylic acid (trolox) were purchased from Sigma Chemical Company (St. Louis, MO, USA); Coomasie Brilliant Blue G-250, acrylamide, bis-acrylamide, low-range molecular-weight standards (phosphorylase B, serum albumin, ovalbumin, carbonic anhydrase, trypsin inhibitor, and lysozyme: 97.4, 66.2, 45.0, 31.0, 21.5, and $14.4 \mathrm{kDa}$, respectively), and tricine from Bio-Rad Hercules, CA, USA); trifluoroacetic acid (TFA) from J.T. Baker (Philipsburg, NJ, USA); L-leucine and trichloroacetic acid from Carlo Erba Reagenti (Rodano, MI, Italy); and Sephadex G-25 fine from GE Healthcare Life Sciences (Uppsala, Sweden). All other chemicals were obtained from local commercial sources and were of the highest purity available.

\subsection{Preparation and partial purification of the plant-protease extract}

Ten mature fruits (approximately $15 \mathrm{~cm}$ in diameter) from $M$. pomifera were collected from a single tree in La Plata city, Province of Buenos Aires, Argentina. Latex $(9.6 \mathrm{~mL})$ was extracted from longitudinal incisions through the skin of the fruit and was collected by dripping into a buffer containing $160 \mathrm{~mL}$ of $0.1 \mathrm{M}$ phosphate, $5 \mathrm{mM}$ EDTA, and $5 \mathrm{mM}$ cysteine, $\mathrm{pH}$ 6.6. This extract-named pomiferin-was centrifuged at $16,000 \mathrm{~g}$ and $4{ }^{\circ} \mathrm{C}$ for $30 \mathrm{~min}$ to remove insoluble materials and partially purified by precipitation with one volume of cold ethanol at $-20{ }^{\circ} \mathrm{C}$ (Corrons et al., 2017). The partially purified extract (PPE) was stored in aliquots of $0.5 \mathrm{~mL}$ at $-20^{\circ} \mathrm{C}$.

\subsection{Determination of the caseinolytic activity and the protein concentration}

The proteolytic activity of the PPE, determined on bovine casein at $37^{\circ} \mathrm{C}$ by the method described by López et al. (2000), was expressed as caseinolytic units per $\mathrm{mL}$ (Ucas/mL), an arbitrary value hereafter defined as the amount of enzyme that produces an increase of one absorbance unit per min under the assay conditions. The concentration of protein in the PPE was evaluated by the Bradford method (1976), with bovine-serum albumin as the standard (range: $100-1000 \mu \mathrm{g} / \mathrm{mL}$ ). The specific activity was calculated as the ratio between the caseinolytic activity and the protein concentration (i.e., Ucas/mg).

\subsection{Preparation of soybean-protein hydrolysate}

A soybean-protein isolate was prepared by extracting $5 \mathrm{~g}$ of defatted soybean flour (Bunge, Buenos Aires, Argentina) with $50 \mathrm{~mL}$ of distilled water (alkalinized to $\mathrm{pH} 8.0$ with $2 \mathrm{~N} \mathrm{NaOH}$ ) at room temperature under constant agitation for $2 \mathrm{~h}$. The suspension was centrifuged at $12,800 \mathrm{~g}$ for $15 \mathrm{~min}$ at $20^{\circ} \mathrm{C}$ and the precipitate discarded. The supernatant was adjusted to $\mathrm{pH} 4.5$ with $2 \mathrm{~N} \mathrm{HCl}$. After a second identical centrifugation, the precipitate was resuspended in distilled water and the $\mathrm{pH}$ adjusted to 8.0 with $2 \mathrm{~N} \mathrm{NaOH}$ (Ortiz \& Wagner, 2002).

Soybean-protein hydrolysates were prepared by mixing $4 \mathrm{~mL}$ of PPE and $36 \mathrm{~mL}$ of soybean-protein isolate (diluted 1/10 in distilled water). The mixtures were incubated at $45^{\circ} \mathrm{C}$ for different times $(10-180 \mathrm{~min})$ under constant stirring. After the hydrolysis, the enzymes contained in PPE were inactivated by heat shock $\left(7 \mathrm{~min}\right.$ at $\left.100^{\circ} \mathrm{C}\right)$. Two controls were carried out by replacing the PPE (substrate blank, SB) and the soybean protein suspension (enzyme blank, EB) with distilled water in the same ratio as was employed in the hydrolysis reaction. The concentration of peptides in the hydrolysates was estimated by the Lowry method (Lowry, Rosebrough, Farr, \& Randall, 1951).

\subsection{Determination of the degree of hydrolysis}

The TNBS method (Adler-Nissen, 1979) was employed to determine the degree of hydrolysis of the hydrolysates. Experimental samples or the standard mixture ( $40 \mu \mathrm{l})$ were added to $320 \mu \mathrm{l}$ of $0.213 \mathrm{M} \mathrm{Na}_{2} \mathrm{HPO}_{4}$ plus $1 \%(\mathrm{w} / \mathrm{v}$ ) sodium dodecyl sulfate (SDS); $\mathrm{pH} 8.2$ and $320 \mu \mathrm{l}$ of $0.5 \%$ (v/v) aqueous TNBS. The mixtures were incubated for $1 \mathrm{~h}$ at $50{ }^{\circ} \mathrm{C}$ in the dark and the reaction stopped after $1 \mathrm{~h}$ by the addition of $640 \mu \mathrm{l}$ of $0.1 \mathrm{M} \mathrm{HCl}$ at room temperature in the dark. The absorbance was then measured at $340 \mathrm{~nm}$ with L-leucine $(0-2.25 \mathrm{mM})$ as a standard. The degree of hydrolysis was expressed as the percent cleavage of peptide bonds with respect to the total number of peptide bonds per protein equivalent (Nielsen, Petersen, \& Dambmann, 2001). 
2.6. Peptide-profile characterization by sodium-dodecylsulfate-polyacrylamide-gel electrophoresis (SDS-PAGE) and reverse-phase high-performance liquid chromatography (RP-HPLC)

The degradation of proteins was visualized by a tricine-SDS-PAGE system (Corrons, Bertucci, Liggieri, López, \& Bruno, 2012). The hydrolysate samples and the corresponding blanks $(100 \mu \mathrm{l})$ were suspended in $100 \mu$ of sample buffer, heated at $100{ }^{\circ} \mathrm{C}$ for $5 \mathrm{~min}$, and centrifuged at $16,000 \mathrm{~g}$ for $15 \mathrm{~min}$. Electrophoresis was performed on a vertical slab cell (Mini Protean III, BioRad, Hercules, CA, USA) containing $16 \%(\mathrm{w} / \mathrm{v})$ polyacrylamide for $3 \mathrm{~h}$ at $90 \mathrm{~V}$. The gels were stained with Coomassie brilliant blue G-250 to visualize the protein bands along with the low-range molecular markers (Bio-Rad) employed.

The peptide profile of the hydrolysates was also checked by RPHPLC. Samples were centrifuged at $16,000 \mathrm{~g}$ for $15 \mathrm{~min}$, and $100 \mu \mathrm{l}$ of each supernatant obtained was applied to a Bondclone ${ }^{\mathrm{TM}} 10 \mathrm{C}-18$ column (3.5 mL, 00H-2117-C0, Phenomenex), operating at room temperature in an ÄKTA-Purifier chromatograph (GE, Uppsala, Sweden) at a flow rate of $0.5 \mathrm{~mL} / \mathrm{min}$. After column equilibration with $15 \mathrm{~mL}$ of Solution 1 ( $0.05 \mathrm{~mL}$ TFA in $100 \mathrm{~mL}$ double-distilled water), each sample was injected on the column, and a linear gradient from 100\% Solution $1-100 \%$ of Solution $2(0.025 \mathrm{~mL}$ TFA in $100 \mathrm{~mL}$ acetonitrile) was applied in 10column volumes ( $35 \mathrm{~mL}$ in total) to obtain a characteristic peptide profile. The elution was monitored by measurement of absorbance at $280 \mathrm{~nm}$.

\subsection{Characterization of hydrolysates by size-exclusion chromatography}

The soybean-protein hydrolysates were characterized by size-exclusion chromatography on a column containing $37 \mathrm{~mL}$ of Sephadex G25 fine. After equilibration of the column with $150 \mathrm{~mL}$ of $0.1 \mathrm{M}$ phosphate buffer $\mathrm{pH} 6.6,400 \mu \mathrm{l}$ of each sample was applied. The elution was carried out at a flow rate of $0.5 \mathrm{~mL} / \mathrm{min}$ at room temperature with the same phosphate buffer employed in the equilibration step. The eluted peptides were detected at $280 \mathrm{~nm}$.

\subsection{Determination of antioxidant activity}

\subsubsection{ABTS-radical-scavenging capacity}

The antioxidant assay was carried out according to Re et al. (1999) with slight modifications. The ABTS radical solution was prepared by dissolving $29 \mathrm{mg}$ of ABTS plus $5 \mathrm{mg}$ of potassium persulfate in $9.6 \mathrm{~mL}$ of distilled water at room temperature in the dark. After $16 \mathrm{~h}$, the solution was diluted with $5 \mathrm{mM}$ phosphate buffer $\mathrm{pH} 7.4$ to a final absorbance at $734 \mathrm{~nm}$ of $0.70 \pm 0.02$ units. The reaction tubes contained $10 \mu \mathrm{l}$ of sample plus $1 \mathrm{~mL} \mathrm{ABTS}{ }^{+}$radical solution; the absorbance at $734 \mathrm{~nm}$ $\left(\mathrm{AS}_{10 \mathrm{~min}}\right)$ was measured after an incubation for $10 \mathrm{~min}$ at room temperature. A negative blank, incubated in parallel containing phosphate buffer instead of the sample, was measured at $0 \mathrm{~min}$ and after $10 \mathrm{~min}$ $\left(\mathrm{AB}_{0 \text { min }}\right.$ and $\mathrm{AB}_{10 \text { min }}$, respectively), while the trolox dilutions (stock concentration of $2.5 \mathrm{mg} / \mathrm{mL}$ ) were likewise incubated as a positive control and a standard for determining the equivalence of the sample. All the measurements were performed in triplicate and reported as the mean value, with the results expressed either as $\mathrm{mg}$ of trolox per $\mathrm{mL}$ or as the trolox-equivalent antioxidant capacity (TEAC) in micromoles of trolox/g of peptide. Accordingly, the percent inhibition of the radical was calculated from the following equation:

$\%$ Inhibition $\mathrm{ABTS}^{+}=\left[\left(\mathrm{AB}_{10 \mathrm{~min}}-\mathrm{AS}_{10 \mathrm{~min}}\right) \times 100\right] / \mathrm{AB}_{0 \text { min }}$

The $50 \%$-inhibitory concentration $\left(\mathrm{IC}_{50}\right.$ ) was expressed as the $\mathrm{mg} /$ $\mathrm{mL}$ of hydrolysate or trolox that scavenged half of the $\mathrm{ABTS}^{+}$radical. This value was calculated on the basis of the final concentration in the cuvette.

The hydrolysate that exhibited the most antioxidant activity was filtered by centrifuging through Amicon Ultra-15 filter units $(30-\mathrm{kDa}$ cut-off, Millipore). This step was carried out with the purpose of removing unwanted aggregates. Finally, this sample was fractionated by size-exclusion chromatography according to Section 2.7 above, and 4-mL aliquots were collected and analyzed for antioxidant activity by the ABTS method.

\subsubsection{Assay of oxygen-radical-absorbance capacity (ORAC)}

The ORAC assay was performed according to the method of Kim, Jang, and Kim (2007) with modifications. Solutions of $53.3 \mathrm{nM}$ fluorescein and $20 \mathrm{mM}$ AAPH, both in $35 \mathrm{mM}$ phosphate buffer (pH 7.8), were first prepared. The reaction mixtures contained $1.5 \mathrm{~mL}$ of fluorescein solution, $250 \mu \mathrm{l}$ of sample, and $250 \mu \mathrm{l}$ of AAPH. Trolox (1-100 mM) solutions were used as a positive control. The decrease in fluorescence per min (at 485-nm emission and 535-nm excitation frequencies) was followed for $35 \mathrm{~min}$ in a spectrofluorometer (Model RF1501, Shimadzu Corporation, Kyoto, Japan). In the fluorescein-decay curves plotted from the data, the difference in the area under the curves between each sample and the blank were calculated and the results expressed as TEAC values.

\subsection{Matrix-assisted-laser-desorption-ionization-time-of-flight mass spectrometry (MALDI-TOF) analysis}

The molecular weights of the filtered hydrolysate with the highest antioxidant activity were investigated by MALDI-TOF MS. The analyses were carried out by CEQUIBIEM (Centro de Estudios Químicos y Biológicos de Espectrometría de Masa, Facultad de Ciencias Exactas y Naturales, Universidad de Buenos Aires, Argentina). The experimental molecular masses were compared with theoretical peptide masses obtained by applying the nonspecific-cleavage tool of the FindPept software (http://web.expasy.org/findpept/) from the database-sequences of major soybean proteins (UniProtKB/Swiss-Prot, protein sequence database; accession numbers: glycinin subunits $\mathrm{A}_{3}$ and $\mathrm{B}_{4}$ : P04347, $\beta$ conglycinin subunits $\alpha, \alpha^{\prime}$, and $\beta$ : P13916, P11827, and P25974, respectively. $\Delta$ mass tolerance: $\pm 0.01 \mathrm{Da}$ ).

\subsection{Statistical analysis}

All the data were reported as the mean \pm the standard deviation of three replicates. The results of antioxidant activity were compared by the one-way analysis of variance ANOVA (GraphPad Prism 6, GraphPad Software Inc., La Jolla, CA 92037 USA). Significant differences between the means of parameters were determined by Tukey's test $(\mathrm{P}<0.05)$. The same software was employed to calculate the area under the curves of the ORAC method.

\section{Results and discussion}

\subsection{Enzymatic extracts and the soybean-protein isolate}

Latex from $M$. pomifera containing peptidases was used to prepare an extract referred to as pomiferin that contained a caseinolytic activity of $7.2 \pm 0.4 \mathrm{Ucas} / \mathrm{mL}$ and a protein content of $1.75 \pm 0.08 \mathrm{mg} / \mathrm{mL}$. In previous studies from our laboratory, crude extracts obtained by the same protocol evidenced a higher caseinolytic activity-i. e., $14.1 \pm 0.8 \mathrm{Ucas} / \mathrm{mL}$ (Corrons et al., 2012), $8.04 \pm 0.21 \mathrm{Ucas} / \mathrm{ml}$ (Bertucci et al., 2015). The proteolytic activity of plant extracts often exhibits variability since the total enzymatic activity from a given plant would depend on the fruit size, the amount of latex recovered, and the quantity of protease present in the latter along with variations according to both the plant's physiology and developmental stage in addition to the prevailing environmental conditions (Schaller, 2004).

In the present experiments, pomiferin was partially purified by ethanol precipitation since this solvent is less toxic than others habitually employed to precipitate proteins. Because the aim of this work was to employ the peptidases in the preparation of a component for potential use as a functional food, we decided to precipitate with 


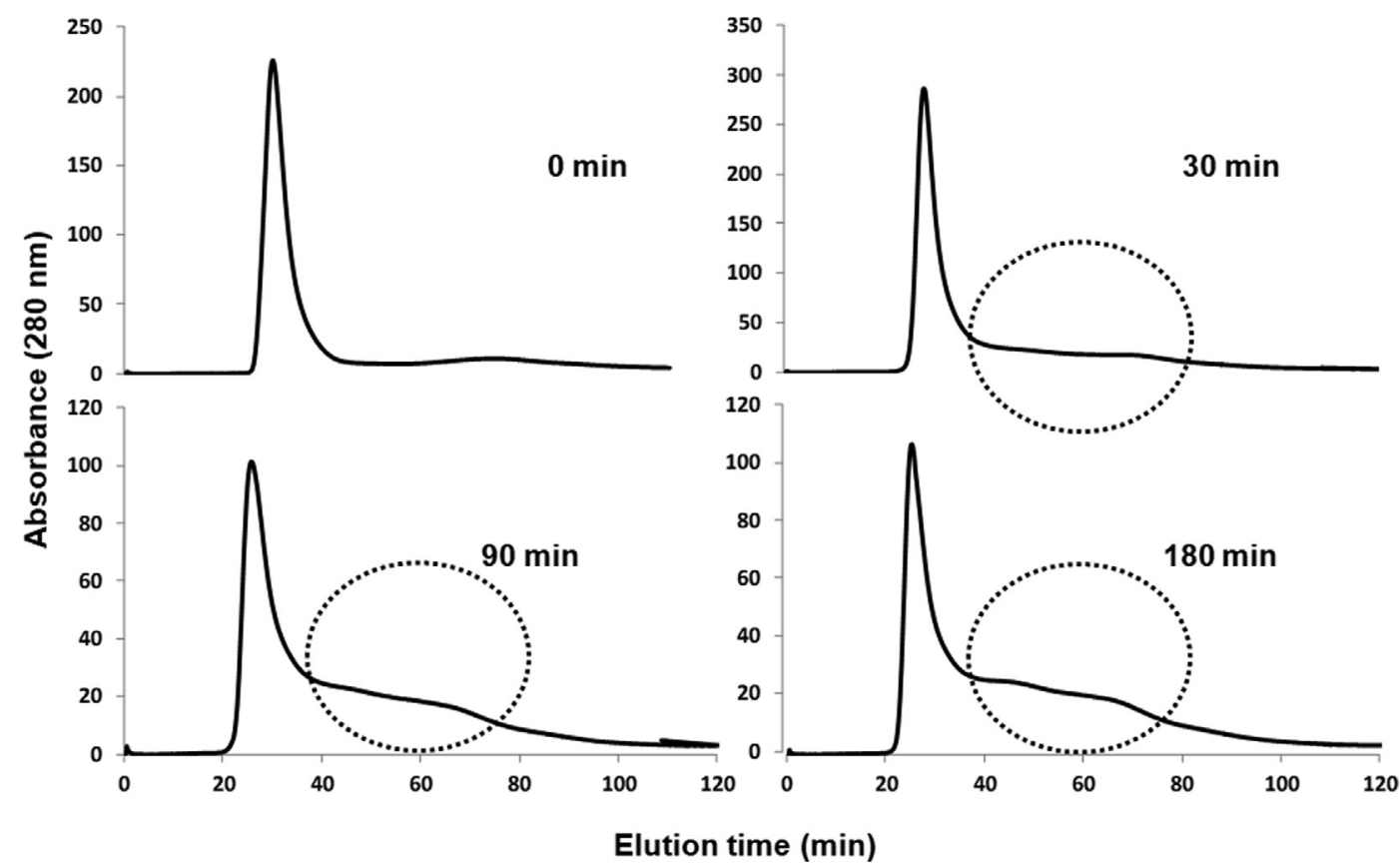

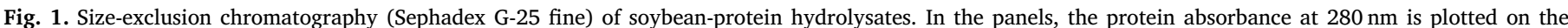

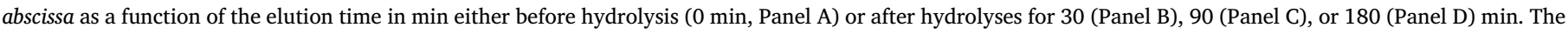
dotted circle denotes the fractions with peptides that appeared as hydrolysis products.

ethanol simply in the unlikely eventuality that traces of the solvent might remain in the final product. The specific activity of the PPE was $3.9 \pm 0.1 \mathrm{Ucas} / \mathrm{mg}$, a value close to the $5.4 \pm 0.4 \mathrm{Ucas} / \mathrm{mg}$ reported by Bertucci et al. (2015).

The substrate for the hydrolysis reactions was a soybean-protein isolate prepared from defatted flour at a final protein content of $41.7 \pm 26 \mathrm{mg} / \mathrm{mL}$. This isolate was diluted $1 / 10$ with distilled water for the preparation of hydrolysates (about $4.2 \mathrm{mg} / \mathrm{mL}$ of protein), and nine volumes of this dilution were mixed with one volume of PPE at $45^{\circ} \mathrm{C}$ under constant stirring. Certain authors-e.g., Ruiz et al. (2013) and Benitez, Ibarz, and Pagan (2008)—recommend a prior denaturation of the globular proteins in order to more completely expose the peptide bonds to the peptidase action. We did not choose this option, though, because during denaturation a portion of the proteins usually undergoes an aggregation that could hamper the hydrolysis reactions.

\subsection{Characterization of soybean-protein-isolate hydrolysates}

The progress of the hydrolysis reaction was followed by different techniques. Fig. 1 depicts the degradation profile as assessed by sizeexclusion chromatography. The absorbance measured at $280 \mathrm{~nm}$ indicated that fragments of lower molecular mass-eluting between 40 and 80 min-increased upon the progression of hydrolysis (denoted by a dotted circle) that were not detected in the run corresponding to the unhydrolyzed substrate. Fig. 2 illustrates the tricine-SDS-PAGE-gel image of the hydrolysates of the soybean-protein isolate, with the main bands of the nonhydrolyzed soybean-protein visualized in lane $0^{\prime}$. In this lane, two bands corresponding to both the acid (A) and the basic (B) subunits of glycinin are visible (at molecular masses of 36 and $22 \mathrm{kDa}$, respectively). The bands corresponding to the different $\beta$-conglycinin subunits ( $\alpha, \alpha^{\prime}$, and $\beta$ ) are of molecular masses between 47 and $67 \mathrm{kDa}$. This profile is in agreement with that obtained in previous studies (Ruiz et al., 2013; Medrano \& Del Castillo, 2011; Zhao, Zhu, \& Chen, 2015). After $10 \mathrm{~min}$ of reaction the main bands of the soybean protein disappeared, and several persistent bands could be observed, one of $18 \mathrm{kDa}$, two close to $14.4 \mathrm{kDa}$, and a broad band corresponding to short peptides ( $<14.4 \mathrm{kDa}$ ). Even though certain authors have found difficulties in hydrolyzing soybean proteins-and particularly the

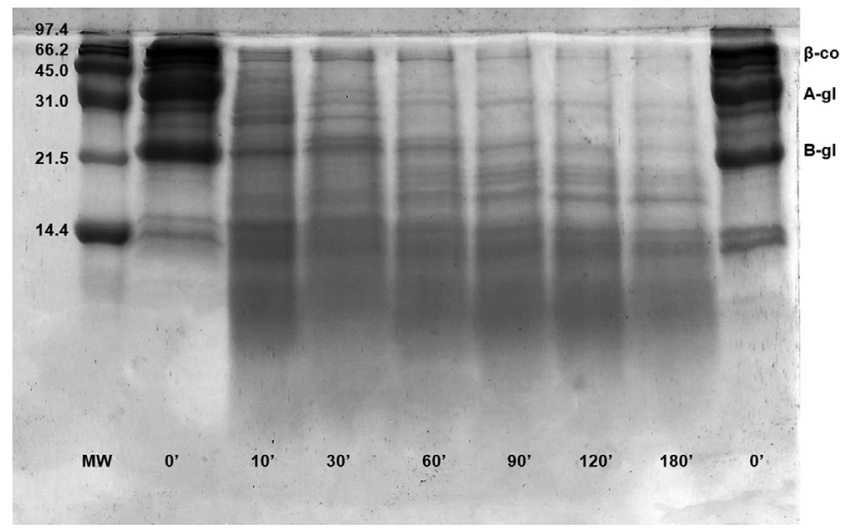

Fig. 2. Tricine SDS-PAGE of the hydrolysates of the soybean-protein isolate. The lanes correspond to the following samples: MW, molecular-weight markers (low range kit, BioRad); $0^{\prime}$, soybean-protein-isolate blank; 10'-180', hydrolysates of the soybean-protein isolate after 10,30,60, 90, 120, and $180 \mathrm{~min}$ of digestion. On the right, the repeated lane $0^{\prime}$ depicts the main soybean-protein isolate. $\beta$-co, $\beta$-conglycinin subunits; A- and B-gl, acid- and basic-glycinin subunits.

subunits of $\beta$-conglycinin because of their glycosylation (Gibbs, Zougman, Masse, \& Mulligan, 2004)—the peptidases of pomiferin readily hydrolyzed those proteins: indeed, the corresponding bands were not present in the gel after only $10 \mathrm{~min}$. Moreover, a study by Aguirre et al. (2008) of the soybean-protein hydrolysates produced by twelve bacterial proteases demonstrated that $\beta$-conglycinin was the fraction preferred by all twelve, but only three exerted an appreciable action against the basic subunit of glycinin. In the present work, glycinin was digested after $90 \mathrm{~min}$ of reaction (Fig. 2), thus exemplifying the high capacity of pomiferin proteases to degrade all the principal soybean proteins.

In addition, the generation of new bands that persist upon reaction progression has been reported in hydrolysates obtained with the peptidases from M. pomifera (Bertucci et al., 2015; Corrons, Liggieri, Trejo, \& Bruno, 2017). Those researches revealed an overall electrophoretic 


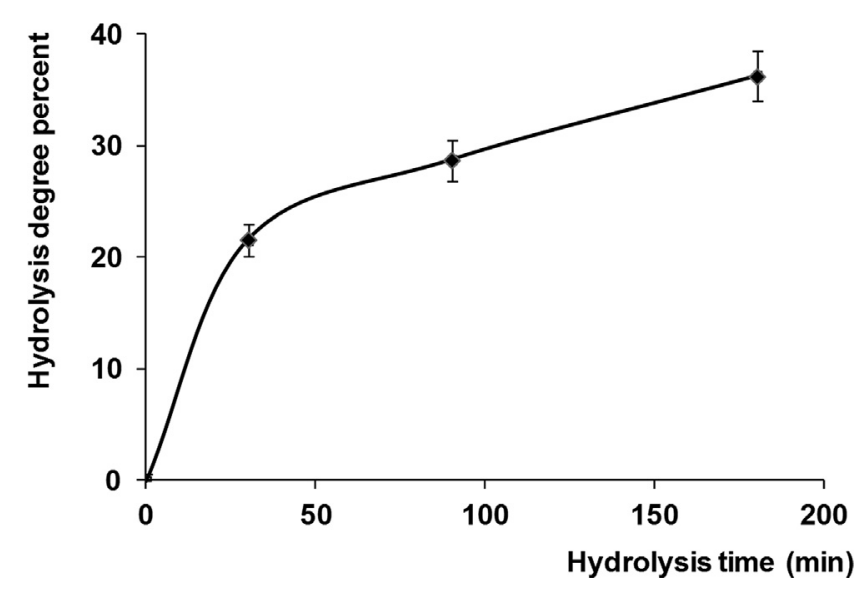

Fig. 3. Degree of hydrolysis of different hydrolysates of the soybean-protein isolate. In the figure, the percent hydrolysis is plotted on the ordinate as a function of hydrolysis time in min on the abscissa. All the determinations were carried out in triplicate. The vertical bars correspond to the standard deviation.

profile that remained essentially unchanged after short hydrolysis times, and the authors concluded that these proteases possess certain peptide-bond specificities for cleavage.

Because the degradation pattern of proteins visualized by SDS-PAGE (Fig. 2) did not indicate considerable differences between the bands corresponding to the hydrolysis times from 10 through $180 \mathrm{~min}$, we selected 30-, 90-, and 180-min of digestion for our further determinations.

Fig. 3 depicts the plot of the degree of hydrolysis vs. the hydrolysis time. An initial linear segment for the first $30 \mathrm{~min}$ reached a value of $21.6 \pm 1.5 \%$, followed by a second linear portion with a considerably decreased slope. The degree of hydrolysis obtained at $180 \mathrm{~min}$ was $36.2 \pm 2.3 \%$, a value close to those reported by Hrčková, Rusňáková, and Zemanovič (2002), for soybean-protein hydrolysates prepared by employing the proteases Alcalase ${ }^{\mathrm{TM}}$, Flavourzyme ${ }^{\mathrm{TM}}$, and Novozym ${ }^{\mathrm{TM}}$ (at respective degrees of hydrolysis of $35.1,39.5$, and $33.3 \%$ ). In that study, the reaction time was much longer than in the present work (i. e., $8 \mathrm{~h}$ ). The possible uses for soybean-protein hydrolysates with these values for the degree of hydrolysis could take advantage of the changes in the peptides' functional properties-such as the foaming and gelation capabilities as well as the release of bioactive peptides, as has been reported in other soybean-protein hydrolysates (Sun, 2011; Meinlschmidt, Sussmann, Schweiggert-Weisz, \& Eisner, 2016).

Fig. 4 summarizes the peptide profiles obtained after hydrolysis as monitored by RP-HPLC. The persistent presence of two peaks in the substrate blank (0 min) and all the hydrolysates (30, 90, and $180 \mathrm{~min}$ ) corresponded to the nondegraded soybean peptides ( $40.6 \mathrm{~min}, 36.8 \%$ Solution 2; $42.9 \mathrm{~min}, 40.9 \%$ Solution 2). The plot of the enzyme blank contained two main peaks at 33.6 and 60.2 min of elution and 27.6 and $65.6 \%$ Solution 2, respectively. After $30 \mathrm{~min}$ of digestion, peptide profile did not undergo a significant further variation. This profile was characterized by a prominent peak at $47.7 \mathrm{~min}$ and $47.7 \%$ Solution 2) and also by the replacement the two broad peaks of the substrate blank (30.2 min, $22.8 \%$ Solution 2; $50.4 \mathrm{~min}, 51.6 \%$ Solution 2) by two corresponding groups containing seven and three new peaks, respectively. These latter details would provide new evidence apparently confirming that the PPE constitutes an enzyme preparation which cuts at specific sites, since these hydrolases would not digest new peptide bonds and thus manifested an invariable digestion profile at progressive hydrolysis times.

\subsection{Antioxidant activity of soybean-protein hydrolysates}

The results for the antioxidant activity of the hydrolysates (by the ABTS method) and the corresponding substrate and enzyme blanks

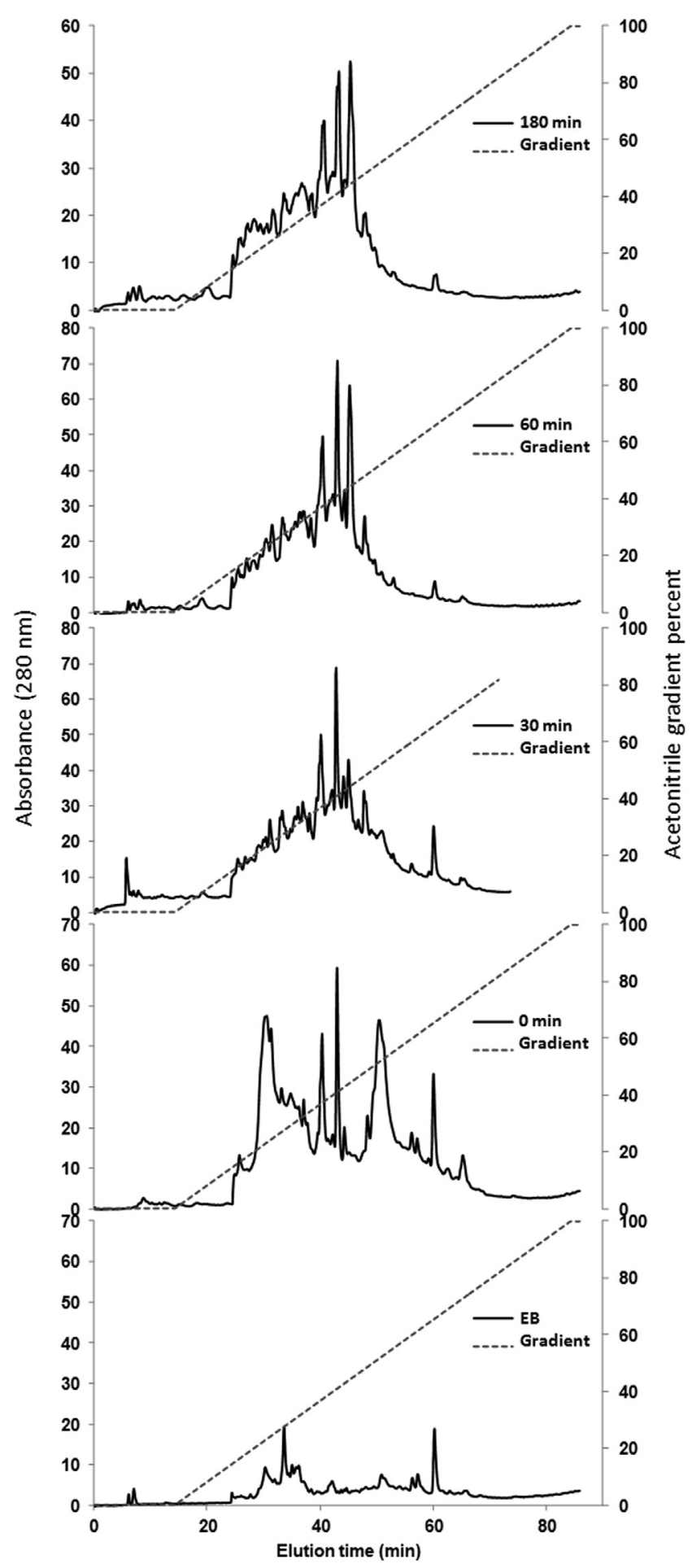

Fig. 4. RP-HPLC of the hydrolysates of the soybean-protein isolate. In the figure, the absorbance at $280 \mathrm{~nm}$ on the left ordinates and the percent acetonitrile in Solution 2 used in the elution profile on the right ordinate pertaining to the ascending dotted lines are plotted as a function of the running time in min on the abscissas. EB, enzyme blank; 0 min, substrate blank; 30, 90, and $180 \mathrm{~min}$, hydrolysates at those tme points. Column: Bondclone ${ }^{\mathrm{TM}} 10 \mathrm{C}-18,00 \mathrm{H}-$ 2117-C0, Phenomenex. Flow rate, $0.5 \mathrm{~mL} / \mathrm{min}$. Elution conditions: linear gradient from $100 \%$ Solution $1(0.05 \mathrm{~mL}$ TFA in $100 \mathrm{~mL}$ water) to $100 \%$ Solution 2 ( $0.025 \mathrm{~mL}$ TFA in $100 \mathrm{~mL}$ acetonitrile), in 10 column volumes.

were analyzed by the ANOVA. The percentages of antioxidant activity of the 30-, 90-, and 180-min hydrolysates were $66.7 \pm 4.1$, $68.7 \pm 2.4$, and $65.2 \pm 1.8 \%$, respectively, and were not significantly 
different ( $\mathrm{p}>0.05$ ), whereas the corresponding respective substrateand enzyme-blank values were $26.1 \pm 2.3$ and $2.1 \pm 0.6 \%$, both at significant differences from those obtained with all the hydrolysates $(\mathrm{p}<0.05)$. The antioxidant activities of the 30-, 90-, and 180-min hydrolysates were also expressed as the trolox-concentration at values of $0.28 \pm 0.02,0.29 \pm 0.01$, and $0.28 \pm 0.01 \mathrm{mg} / \mathrm{mL}$, respectively.

We selected the 90-min hydrolysate for further study since after only 90 min of digestion no substantial further changes in the digestion profile occurred, thus rendering a longer hydrolysis time, such as $180 \mathrm{~min}$, unnecessary. Furthermore, whereas the SDS-PAGE profiles indicated that the values corresponding to 30 and $90 \mathrm{~min}$ of reaction were similar, a complete degradation of the relevant bands had not yet occurred after only $30 \mathrm{~min}$ of hydrolysis. Thus, for this reason, the 30 min hydrolysate was not considered.

The TEAC value is an expression of antioxidant activity that enables a comparison of antioxidant capability between different laboratories. The TEAC value for the 90 -min hydrolysate was $157.6 \mu$ moles TE/g of peptide, as assesed by the ABTS method, and was $176.9 \mu$ moles TE/g peptide by the ORAC determination. These results are in the same order of magnitude as those reported by Medrano and Del Castillo (2011), who hydrolyzed glycinin using proteases from Streptomyces griseus and Aspergillus oryzae (i.e., Flavourzyme ${ }^{\mathrm{TM}}$ ) for $3 \mathrm{~h}$, reporting values of $180-220 \mu \mathrm{mol} \mathrm{TE} / \mathrm{g}$. Afterwards, we calculated the $\mathrm{IC}_{50}$ for this hydrolysate and for trolox, and we obtained values of $31.6 \pm 0.2$ and $3.2 \pm 0.1 \mu \mathrm{g} / \mathrm{mL}$, respectively. This latter was almost the same reported by Fitriana, Ersam, Shimizu, and Fatmawati. (2016) whose value obtained was $3.06 \mu \mathrm{g} / \mathrm{mL}$ by using the same method.

The hydrolysate of $90 \mathrm{~min}$ was filtered through a $30-\mathrm{kDa}$-cut-off membrane. The antioxidant activity recovered in this filtrate retained $71 \%$ of the original activity, as assessed by the ABTS method and $87 \%$ by the ORAC determination. A comparison between data obtained by different methods is usually difficult because of the lack of a single antioxidant standard, a uniform radical concentration, and equivalent experimental conditions.

After the filtration, the sample was analyzed by size-exclusion chromatography and the resulting fractions evaluated by the ABTS method. Fig. 5 depicts the antioxidant activity, expressed in $\mathrm{mg} / \mathrm{mL}$ of trolox for each of the elution tubes (ten fractions). The highest antioxidant activity was observed in the first two tubes, with the activity decreasing after fraction number 3 . The values of antioxidant activity corresponding to the fractions $8-10$ were ignored because the ANOVA indicated no significant differences from that of the negative control ( $\mathrm{p}>0.05)$.

\subsection{Analysis by MALDI-TOF MS}

The molecular masses of the 90-min hydrolysate filtered through the $30-\mathrm{kDa}$-cut-off membrane were analyzed by MALDI-TOF MS. The resulting fragments constituted about 40 peaks over the background smaller than $8 \mathrm{kDa}$, whose intensities were greater than 200 arbitrary units (Supplementary material). These mass values were used to carry out a bioinformatics analysis by means of the FindPept software tool for nonspecific cleavage along with a comparison of those fragments with the sequences of major soybean proteins. Table 1 summarizes the theoretical sequences of peptides present in the hydrolysate, their position in the original soybean protein, and the percentage of antioxidant amino acids according to studies previously reported. In those results, amino acids such as Thr, Met, Cys, Phe, Tyr, His, Gly, Trp, Ala, Val, Leu, and Lys (T, M, C, F, Y, H, G, W, A, V, L, and K in the table, respectively) were considered the ones responsible for the antioxidant capability of the peptides that contained them (Sarmadi \& Ismail, 2010; Wang, Zhao, Zhao, \& Jiang, 2007).

Likewise, the percentage of antioxidant amino acids was calculated for two peptides found in previous investigations. Thus, the peptides SHCMN (Lin, Liang, Li, Xing, \& Yuan, 2016), and FDPAL (Ma et al., 2016) from soybean protein both presented a percentage of antioxidant amino acids of $60 \%$.

On basis of these results, in Table 1 the peptides with a composition of antioxidant amino acids equal to or greater than $60 \%$ (denoted with an asterisk in Table 1) were selected as potentially being responsible for the antioxidant activity of the 90-min hydrolysate.

From the analysis of the sequences listed in Table 1, 14 candidates were found, none having been previously reported as antioxidant peptides-namely, 2, 1, 5, 4, and 2 from A3-glycinin, B4-glycinin and the $\alpha$-, $\alpha^{\prime}$-, and $\beta$-subunits of $\beta$-conglycinin, respectively).

We thus considered that the initial hypothesis of the present work was verified because the peptidases from $M$. pomifera were able to hydrolyze the soybean proteins. This conclusion was verified through the monitoring of the hydrolysis products by different methods. Moreover, antioxidant activity was found in the hydrolysates, which capability was attributed to the presence of bioactive peptides released from the soybean proteins.

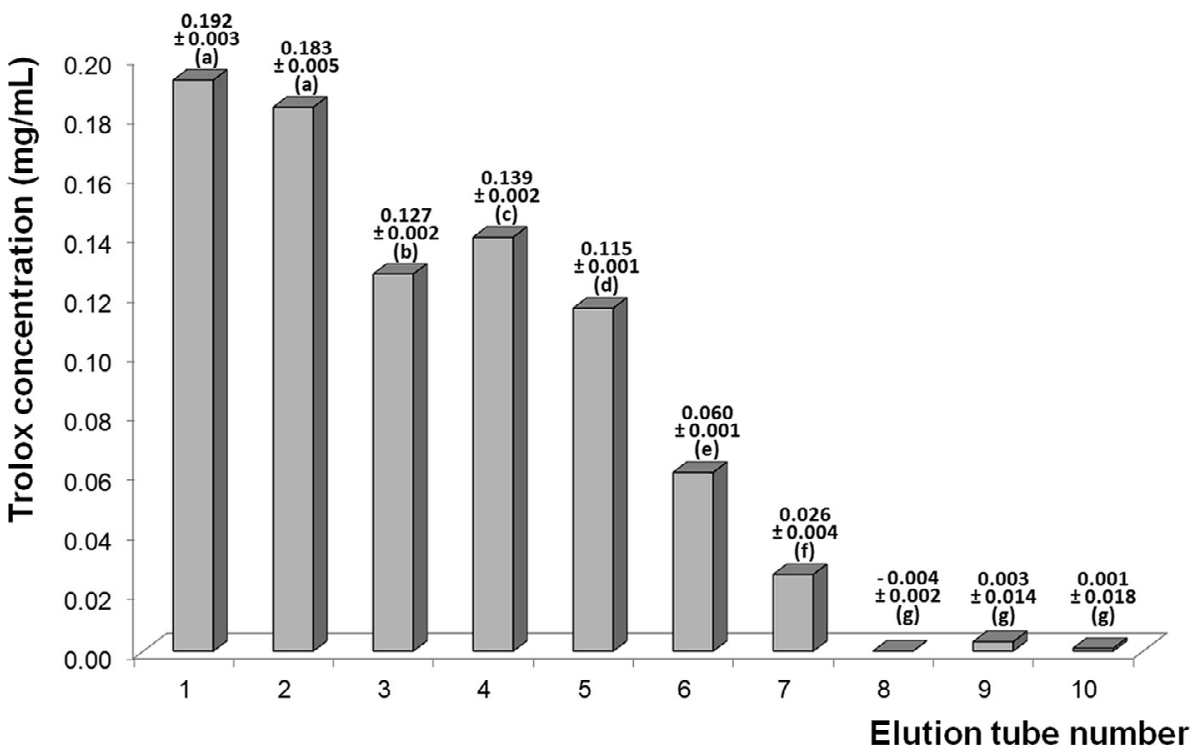

Fig. 5. Antioxidant activity of the fractions of the filtered 90-min hydrolysate obtained by molecularsize chromatograhy. In the figure, the trolox concentration in $\mathrm{mg} / \mathrm{mL}$ is plotted on the ordinate for the sequential elution fractions obtained from the Sephadex G-25 column denoted on the abscissa expressed as the tube numbers. Labels over bars: Trolox $(\mathrm{mg} / \mathrm{mL})$ value $\pm \mathrm{SD}$; same letter indicates values with no significant difference $(\mathrm{P}>0.05)$. 
Table 1

Theoretical sequences of peptides present in the 90-min filtered hydrolysate within the sequences of A- and B-glycinin and $\alpha$-, $\alpha^{\prime}$ - and $\beta$-, $\beta$-conglycinin. The position of the peptide within the protein of origin corresponding to the number in the amino-acid sequence within that precursor of these proteins is listed in the Position column. The experimental and theoretical mass-value matches were selected with a mass tolerance of $\pm 0.01 \mathrm{Da}$. The white letters on the black background correspond to the single-letter amino-acid abbreviations within the sequences that exhibited antioxidant activity. The percentage of antioxidant amino acids was calculated with respect to the total number in each peptide sequence. The asterisk $\left(^{*}\right)$ denotes peptides with a composition of antioxidant amino acids equal to or greater than $60 \%$ that were selected as potentially being responsible for the antioxidant activity of the 90-min hydrolysate.

\begin{tabular}{|c|c|c|c|c|}
\hline $\begin{array}{l}\text { Original } \\
\text { protein }\end{array}$ & $\begin{array}{l}\text { User } \\
\text { mass }\end{array}$ & Peptide & Position & $\begin{array}{c}\text { Percent } \\
\text { antioxidant } \\
\text { amino acid in } \\
\text { peptide } \\
\text { sequence }\end{array}$ \\
\hline \multirow{7}{*}{ 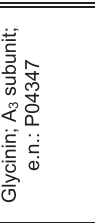 } & 1133.616 & (N) RRVFYLAGNP (D) & 184-193 & $60.0\left(^{*}\right)$ \\
\hline & 1164.621 & (D) QNPRVFYLAG (N) & $182-191$ & $60.0\left(^{*}\right)$ \\
\hline & 1298.686 & (K) IRHENEGDVLV (I) & $138-148$ & 54.5 \\
\hline & 1298.686 & (I) RHFNEGDVLVI (P) & 139-149 & 54.5 \\
\hline & 1458.742 & (S) HIPSYIPYPQMI (I) & $82-93$ & 50.0 \\
\hline & 1458.742 & (S) RRGSRSQQRIQD (S) & $122-133$ & 16.6 \\
\hline & 1633.837 & 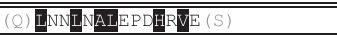 & $35-48$ & 42.8 \\
\hline \multirow{5}{*}{ 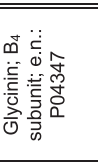 } & 1176.607 & (L) KYQGNSGPLVN (P) & $505-515$ & 54.5 \\
\hline & 1176.607 & (G) NAVFDGEZRR (G) & $432-441$ & 50.0 \\
\hline & 1176.607 & (A) VFDGELRRGQ (L) & $434-443$ & 50.0 \\
\hline & 1384.729 & (F) KTHHNAVSSYIK (D) & $468-479$ & $66.6\left(^{*}\right)$ \\
\hline & 1651.899 & (S) SYIKDVERVIPSE (I) & $476-489$ & 42.8 \\
\hline \multirow{19}{*}{ 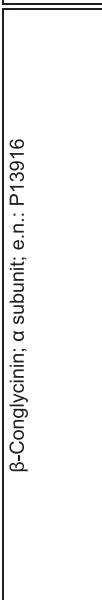 } & 1005.590 & (D) YLIVILNGT (A) & $255-263$ & $66.6\left(^{*}\right)$ \\
\hline & 1133.616 & (F) NZRSRDPIY (S) & $407-415$ & 22.2 \\
\hline & 1148.621 & (A) DADIDIIVILN (G) & $252-261$ & 50.0 \\
\hline & 1181.655 & (L) FKNQYGRIR (V) & $207-215$ & 44.4 \\
\hline & 1395.789 & (E) TLFKNQYGRIR (V) & $205-215$ & 18.2 \\
\hline & 1402.721 & (N) REETLEKNQYG (R) & $202-212$ & $63.6\left(^{*}\right)$ \\
\hline & 1402.721 & (R) EETLFKNQYGR (I) & $203-213$ & $63.6\left(^{*}\right)$ \\
\hline & 1402.721 & (R) FNKNPFLFGSN (R) & 190-201 & 16.7 \\
\hline & 1458.742 & (I) LNGTAILSLVNNDD (R) & $260-273$ & 50.0 \\
\hline & 1605.834 & (D) SYRLQSGDAIRVPSG (T) & $276-290$ & 33.3 \\
\hline & 1605.834 & (P) FLFGSNRFETLFK $(\mathrm{N})$ & 196-208 & $69.2\left(^{*}\right)$ \\
\hline & 1651.899 & (E) I国PEKNPQLRDLDI (E) & $425-438$ & 28.5 \\
\hline & 1651.899 & (L) SRRAKSSSRKTISSE (D) & $388-402$ & 33.3 \\
\hline & 1667.903 & (N) TLLIPNHADADYIIV (I) & $244-258$ & $66.6\left(^{*}\right)$ \\
\hline & 1780.937 & (Q) LQNURDYRIIEGNS (K) & $227-240$ & 35.7 \\
\hline & 1780.937 & (F) EITPEKNPQIRDIDI (F) & $424-438$ & 26.6 \\
\hline & 1793.982 & (L) LIPNHADADYLIVILN (G) & $246-261$ & 56.2 \\
\hline & 1908.991 & (P) QIQNLRDYRILEGNS (K) & $226-240$ & 33.3 \\
\hline & 2395.285 & (E) DKPFNLRSRDPIYSNKLGKE (E) & $403-422$ & 45.0 \\
\hline \multirow{15}{*}{ 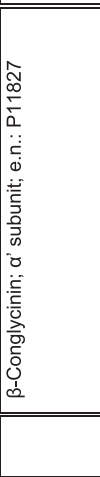 } & 1005.590 & (D) YLIVILNGT (A) & $271-279$ & $66.6\left(^{*}\right)$ \\
\hline & 1148.621 & (R) $\overline{\text { ENKRSQQLQ (N) }}$ & $236-244$ & 33.3 \\
\hline & 1148.621 & (A) DADILIVILN (G) & $268-277$ & 50.0 \\
\hline & 1148.621 & (Y) LoGESKKNILE (A) & 369-378 & 50.0 \\
\hline & 1176.607 & (A) EPRSAKDIEN (L) & 593-602 & 30.0 \\
\hline & 1298.686 & (K) PNTLLIP HHAD䊓 (D) & $258-269$ & $66.6\left(^{*}\right)$ \\
\hline & 1347.660 & (K) VLFGREEGQQQ (E) & $391-402$ & 50.0 \\
\hline & 1514.840 & (K) LFEITQRNPQIR (D) & $457-468$ & 33.3 \\
\hline & 1605.834 & (Q) DIEVIPAGYPVMVNম (T) & $538-552$ & 60.0 \\
\hline & 1780.937 & (Q) LeNLRDYRIIEENS (K) & $243-256$ & 35.7 \\
\hline & 1908.991 & (Y) NZQSGDAIRVPAGTTFYV (V) & $294-311$ & $66.6\left(^{*}\right)$ \\
\hline & 1908.991 & (Q) QLeNLRDYRILEGNS (K) & $242-256$ & 33.3 \\
\hline & 2196.223 & (P) QQKEEGNKGRKGPLSSILRA $(E)$ & 618-637 & 45.0 \\
\hline & 2395.285 & (H) KNKNDEHFNSKREOTLFKN (Q) & $207-225$ & 57.8 \\
\hline & 2395.285 & (R) FeTLFKNQYGHVRVLQRE $N(K)$ & $219-237$ & $63.1\left(^{*}\right)$ \\
\hline \multirow{14}{*}{ 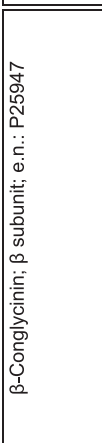 } & 1005.590 & 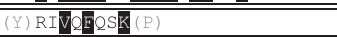 & $73-80$ & 37.5 \\
\hline & 1164.621 & (L) RDLDIFISSV (D) & $268-277$ & 40.0 \\
\hline & 1176.607 & (N) NQRNFLAGEK (D) & $368-377$ & 50.0 \\
\hline & 1298.686 & (K) PNTILIPHHAD国 (D) & $81-92$ & 58.3 \\
\hline & 1605.834 & (I) DIEISSVDINEGALI (L) & $271-285$ & 46.6 \\
\hline & 1605.834 & (D) LDIFLSSVDINEGAI (L) & $270-284$ & $60.0\left(^{*}\right)$ \\
\hline & 1651.899 & (E) ITPERNPQLRDLDI (F) & $259-272$ & 28.6 \\
\hline & 1663.947 & (Q) LSRRAKSSSRKTISS (E) & $221-235$ & 33.3 \\
\hline & 1780.937 & (Q) LENLRDVRIVDEQS (K) & 66-79 & 35.7 \\
\hline & 1780.937 & (F) EITPEKNPQIRDIDI (F) & $258-272$ & 26.6 \\
\hline & 1908.991 & (N) NFGKFEEITPEKNPQI (R) & $252-267$ & $\overline{50.0}$ \\
\hline & 1908.991 & (I) PAAYPEVVNATSNLNELA (E) & $343-360$ & $66.6\left(^{*}\right)$ \\
\hline & 1908.991 & (P) QLENLRDYRIVQERS (K) & $65-79$ & 33.3 \\
\hline & 2485.274 & (F) VISGRALILTVNNDDRDS N $\quad$ (P) & 98-119 & 50.0 \\
\hline
\end{tabular}

\section{Conclusions}

Nowadays, in the food industry, soybean-protein hydrolysates are employed as a high-priced value-added ingredient. Protein hydrolysates possess a higher digestibility than the original proteins. A food of this type has proven to be of interest for consumption by people with difficulties in the intestinal absorption of proteins, with various chronic diseases, or with allergies. In addition, protein hydrolysates are commonly included in sports nutritional regimes.

In the present work, we have prepared hydrolysates of soybean proteins employing peptidases from $M$. pomifera with antioxidant activity. We deduced the theoretical sequences of several peptides that we consider to be most likely responsible for this activity. In order to corroborate these sequences, future work should be directed at analyzing selected hydrolysates by MALDI-TOF/TOF MS/MS so as to obtain the real sequences by fragmentation and thus to acquire additional information about these reaction products. For the present, we consider that this 90 -min pomiferin hydrolysate constitutes a promising ingredient for inclusion in the manufacture of functional foods.

\section{Acknowledgements}

This work was supported by grants from ANPCyT (PICT-20132531), University of La Plata, Argentina (Projects X-746 and X-682). Andrea M. Reyes Jara is a CONICET fellow, Dr. Constanza S. Liggieri is a member of CIC Support Professional Career program, and Mariela A. Bruno is a career member of CONICET. The MALDI-TOF MS analyses were carried out in the CEQUIBIEM. Dr. Donald F. Haggerty, a retired academic career investigator and native English speaker, edited the final version of the manuscript.

\section{Appendix A. Supplementary data}

Supplementary data associated with this article can be found, in the online version, at https://doi.org/10.1016/j.foodchem.2018.05.013.

\section{References}

Abu-Salem, F. M., Mahmoud, M. H., El-Kalyoub, M. H., Gibriel, A. Y., \& Abou-Arab, A. (2013). Characterization of antioxidant peptides of soybean protein hydrolysate. In Proceedings of world academy of science, engineering and technology (pp. 522-528). World Academy of Science, Engineering and Technology (WASET). doi: 10.1999/ 1307-6892/16297.

Adler-Nissen, J. (1979). Determination of the degree of hydrolysis of food protein hydrolysates by trinitrobenzenesulfonic acid. Journal of Agricultural and Food Chemistry, 27, 1256-1262.

Aguirre, L., Garro, M. S., \& de Giori, G. S. (2008). Enzymatic hydrolysis of soybean protein using lactic acid bacteria. Food Chemistry, 111, 976-982.

Ahmed, A. S., El-Bassiony, T., Elmalt, L. M., \& Ibrahim, H. R. (2015). Identification of potent antioxidant bioactive peptides from goat milk proteins. Food Research International, 74, 80-88.

Akbarirad, H., Gohari Ardabili, A., Kazemeini, S. M., \& Mousavi Khaneghah, A. (2016). An overview on some of important sources of natural antioxidants International. Food Research Journal, 23, 928-933.

Benitez, R., Ibarz, A., \& Pagan, J. (2008). Protein hydrolysates: Processes and applications. Acta Bioquímica Clínica Latinoamericana, 42, 227-236.

Bertucci, J. I., Liggieri, C. S., Colombo, M. L., Vairo Cavalli, S. E., \& Bruno, M. A. (2015) Application of peptidases from Maclura pomifera fruit for the production of active biopeptides from whey protein. LWT-Food Science and Technology, 64, 157-163.

Bradford, M. M. (1976). A rapid and sensitive method for the quantitation of microgram quantities of protein utilizing the principle of protein-dye binding. Analytical Biochemistry, 72, 248-254.

Corrons, M. A., Bertucci, J. I., Liggieri, C. S., López, L. M. I., \& Bruno, M. A. (2012). Milk clotting activity and production of bioactive peptides from whey using Maclura pomifera proteases. Food Science and Technology, 47, 103-109.

Corrons, M. A., Liggieri, C. S., Trejo, S. A., \& Bruno, M. A. (2017). ACE-inhibitory peptides from bovine caseins released with peptidases from Maclura pomifera latex. Food Research International, 93, 8-15.

De Castro, R. J. S., \& Sato, H. H. (2015). Biologically active peptides: Processes for their generation, purification and identification and applications as natural additives in the food and pharmaceutical industries. Food Research International, 74, 185-198.

Erdmann, K., Cheung, B. W., \& Schröder, H. (2008). The possible roles of food-derived bioactive peptides in reducing the risk of cardiovascular disease. The Journal of nutritional biochemistry, 19, 643-654. 
Evangelho, J. A. D., Berrios, J. D. J., Pinto, V. Z., Antunes, M. D., Vanier, N. L., \& Zavareze, E. D. R. (2016). Antioxidant activity of black bean (Phaseolus vulgaris L.) protein hydrolysates. Food Science and Technology (Campinas), 36, 23-27.

Fitriana, W. D., Ersam, T., Shimizu, K., \& Fatmawati, S. (2016). Antioxidant activity of Moringa oleifera extracts. Indonesian Journal of Chemistry, 16, 297-301.

Gibbs, B. F., Zougman, A., Masse, R., \& Mulligan, C. (2004). Production and character ization of bioactive peptides from soy hydrolysate and soy-fermented food. Food Research International, 37, 123-131.

Griffiths, K., Aggarwal, B. B., Singh, R. B., Buttar, H. S., Wilson, D., \& De Meester, F. (2016). Food antioxidants and their anti-inflammatory properties: A potential role in cardiovascular diseases and cancer prevention. Diseases, 4, 28. http://dx.doi.org/10. 3390/diseases4030028.

Hrčková, M., Rusňáková, M., \& Zemanovič, J. (2002). Enzymatic hydrolysis of defatted soy flour by three different proteases and their effect on the functional properties of resulting protein hydrolysates. Czech Journal of Food Sciences, 20, 7-14.

Kim, G. N., Jang D. H., \& Kim, C. I. Antioxidant capacity of caseinophosphopeptide prepared from sodium caseinate using Alcalasa. Food Chemistry, 104, 1359-1365.

Kumar, S. (2011). Free radicals and antioxidants: Human and food system. Advances in Applied Science Research, 2, 129-135.

Li-Chan, E. C. (2015). Bioactive peptides and protein hydrolysates: Research trends and challenges for application as nutraceuticals and functional food ingredients. Current Opinion in Food Science, 1, 28-37.

Lin, S., Liang, R., Li, X., Xing, J., \& Yuan, Y. (2016). Effect of pulsed electric field (PEF) on structures and antioxidant activity of soybean source peptides-SHCMN. Food Chemistry, 213, 588-594.

Lobo, V., Patil, A., Phatak, A., \& Chandra, N. (2010). Free radicals, antioxidants and functional foods: Impact on human health. Pharmacognosy Reviews, 4, 118-126.

López, L. M., Sequeiros, C., Natalucci, C. L., Brullo, A., Maras, B., Barra, D., et al. (2000). Purification and characterization of macrodontain I, a cysteine peptidase from unripe fruits of Pseudananas macrodontes (Morr.) Harms (Bromeliaceae). Protein Expression and Purification, 18, 133-140.

Lowry, O. H., Rosebrough, N. J., Farr, A. L., \& Randall, R. J. (1951). Protein measurement with the Folin phenol reagent. The Journal of Biological Chemistry, 193, 265-275.

Ma, H., Liu, R., Zhao, Z., Zhang, Z., Cao, Y., Ma, Y., et al. (2016). A novel peptide from soybean protein isolate significantly enhances resistance of the organism under oxidative stress. PLOS ONE, 11, e0159938.

Medrano, A., \& Del Castillo, M. D. (2011). Obtención de péptidos antioxidantes de glicinina de soja. INNOTEC-Revista del Laboratorio Tecnológico del Uruguay, 6, 32-36.
Meinlschmidt, P., Sussmann, D., Schweiggert-Weisz, U., \& Eisner, P. (2016). Enzymatic treatment of soy protein isolates: Effects on the potential allergenicity, technofunctionality, and sensory properties. Food Science \& Nutrition, 4, 11-23.

Nielsen, P. M., Petersen, D., \& Dambmann, C. (2001). Improved method for determining food protein degree of hydrolysis. Journal of Food Science, 66, 642-646.

Ortiz, S. E. M., \& Wagner, J. R. (2002). Hydrolysates of native and modified soy protein isolates: Structural characteristics, solubility and foaming properties. Food Research International, 35, 511-518.

Peng, C., Wang, X., Chen, J., Jiao, R., Wang, L., Li, Y. M., \& Huang, Y. (2014). Biology of ageing and role of dietary antioxidants. BioMed research international, Article ID 831841 .

Puchalska, P., Marina, M. L., \& García, C. (2014). Isolation and Identification of antioxidant peptides from commercial boybean-based infant formulas. Food Chemistry, 148, 147-154.

Re, R., Pellegrini, N., Proteggente, A., Pannala, A., Yang, M., \& Rice-Evans, C. (1999). Antioxidant activity applying an improved ABTS radical cation decolorization assay. Free Radical Biology and Medicine, 26, 1231-1237.

Ruiz, E. I. J., Calderón de la Barca, A. M., Sotelo-Mundo, R. R., Arteaga-Mackinney, G. E., Valenzuela-Melendez, M., \& Peña-Ramos, A. E. (2013). Partial characterization of ultrafiltrated soy protein hydrolysates with antioxidant and free radical scavenging activities. Journal of Food Science, 78, 1152-1158.

Sarma, A. D., Mallick, A. R., \& Ghosh, A. K. (2010). Free radicals and their role in different clinical conditions: An overview. International Journal of Pharma Sciences and Research, 1, 185-192.

Sarmadi, B. H., \& Ismail, A. (2010). Antioxidative peptides from food proteins: A review. Peptides, 31, 1949-1956.

Schaller, A. (2004). A cut above the rest: The regulatory function of plant proteases. Planta, 220, 183-197.

Sun, X. D. (2011). Enzymatic hydrolysis of soy proteins and the hydrolysates utilisation. International Journal of Food Science \& Technology, 46, 2447-2459.

Waly, M. I., \& Guizani, N. (2016). Health aspects of antioxidant nutrients: A concise update. Journal of Agricultural Research, 1, 1-6.

Wang, J., Zhao, M., Zhao, Q., \& Jiang, Y. (2007). Antioxidant properties of papain hydrolysates of wheat gluten in different oxidation systems. Food Chemistry, 101 1658-1663.

Zhao, X., Zhu, H., \& Chen, J. (2015). Effects of sodium bis (2-ethylhexyl) sulfo succinate (AOT) reverse micelles on physicochemical properties of soy protein. Food and Bioproducts Processing, 94, 500-506. 